\title{
A study on the protective effect of Zizyphus spina christi extract on hepatic ischemia-reperfusion-induced injury.
}

Shima H. EL-Fayoumi ${ }^{1}$, Mohammed N. Zakaria ${ }^{1}$, and Nabila N. EL-Maraghy ${ }^{2}$

${ }^{1}$ Department of Pharmacology, Faculty of Pharmacy, Zagazig University, 44519, Egypt

${ }^{2}$ Faculty of pharmacy, Future University, Cairo, Egypt

\section{ABSTRACT}

The objective of the study was to study the protective effect of Zizyphus spina christi extract $(Z S C)$ on hepatic ischemia-reperfusion (I/R) injury in rats. Rats were randomly divided into four groups.Ischemia /reperfusion (I/R) groups, were received p.o saline, p.o $(Z S C)$ (400 mg/ $\mathrm{kg}) 60 \mathrm{~min}$ before surgery and rats were I.P. injected with $30 \mathrm{mg} / \mathrm{kg}$ Bisphenol A diglycidyl ether (BADGE) 30 minutes prior to administration of $(Z S C)$. I/R caused increase level of liver enzymes AST, ALT, ALP and LDH, also it increased level of proinflammatory mediators TNF- $\alpha$, NO, and MDA. Whereas I/R caused significant decrease on IL-10, SOD, and GSH. The current study showed that ZSC extract protects liver against I/R since it increased antioxidants, reduced liver enzymes and inhibited the inflammatory mediators. On the other hand, injection of BADGE attenuates the effect of ZSC extract on the measured parameters. The study indicates that ZSC exerts antioxidant and anti-inflammatory effect in ischemic liver. This effect may be through the peroxisome proliferator-activated receptor-gamma $(\operatorname{PPAR} \gamma)$.

\section{INTRODUCTION}

Hepatic ischemia-reperfusion injury is a kind of severe clinical pathophysiological change, which is usually divided into the ischemia period and reperfusion period. The major pathophysiological manifestations in the ischemia period only include the structural changes in membrane potential and metabolic acidosis caused by changes in intracellular calcium ion concentration. But changes in liver function are not significant, and the damage is less severe. While in the reperfusion period, injury is significantly exacerbated. Liver function indices change significantly, even giving rise to related complications (Shaojun, 2013).

Moreover, it has been reported that, hepatic $\mathrm{I} / \mathrm{R}$ is a complicated multistep antigen-independent event, which includes kupffer cell activation, ROS generation, lipid peroxidation, neutrophil infiltration, increased expression of adhesion molecules, and cytokine release, as well as hepatocyte damage (Zhang et al., 2007).

Several pharmacological studies have been focused on the various species of Zizyphus (Rhamnaceae) (Nunes et al., 1987; Adzu et al., 2001; Borgi et al., 2007). The species of Zizyphus indigenous to Tunisia, $Z$. lotus, was tested for its anti-inflammatory activity. Moreover, Borgi et al. (2007) have reported that the aqueous and methanolic extracts of $Z$. lotus root barks show a significant anti-inflammatory effect in the acute phase of the inflammatory process as compared with NSAIDs products.

In accordance to Zizyphusspina-christ (ZSC), a number of studies were done and proved some pharmacological activities of ZSC extract against some diseases that have a great relation to inflammation, including diabetes mellitus (Glombitza et al., 1994), hepatic carcinogenicity (Abdel-Wahhab et al., 2005) and hyperlipidemia (Hussein et $a l ., 2006)$, in addition to the traditional use 
of the plant in inflammation (Abdel-Zaher et al., 2005).

From this point of view, it was interesting to investigate the protective, antioxidant, and anti-inflammatory effects that ZSC ethanol extract may possess, taking in consideration the similarity in the chemical composition between the several species of Zizyphus and the folkloric use of ZSC.

\section{MATERIALS and METHODS:}

\section{Animals:}

Sixty-six adult male rats (180-250g; Zagazig University, Zagazig, Egypt) were used in the present study. All animals were maintained under standard husbandary condition with food and water. The experimental procedures were approved by the Institutional Animal Ethics Committee of the Faculty of Pharmacy, Zagazig University and animals were handled following the International Animal Ethics Guidelines, ensuring minimum animal suffering.

\section{Study protocol:}

Animals were randomly divided into four experimental groups (each containing ten animals): sham, ischemia/reperfusion (I/R) injury, ZSC extract (400 mg/kg) and Bisphenol A diglycidyl ether (BAGE) with ZSC extract. Sham group received saline then anesthetized, the hepatic artery and portal vein exposed but not occluded. Rats of $\mathrm{I} / \mathrm{R}$ group were anesthetized by i.p injection of pentobarbital $(50 \mathrm{mg} / \mathrm{kg})$ and subjected to partial liver ischemia (70\%) followed by reperfsion. Ischemia was induced by occluding branches of hepatic artery and hepatic portal vein with bulldog clamp. After $45 \mathrm{~min}$ of ischemia, the clamp was removed to start reperfusion for $60 \mathrm{~min}$. ZSC was dissolved in gum acacia $(8 \%)$ then given orally as a single dose $60 \mathrm{~min}$ before ischemia .BAGE was dissolved in DMSO
(70\%) then given i.p 30 before administration of ZSC. Blood was collected from the retro-orbital plexus and centrifuged $\left(3000 \mathrm{~g} \times, 4^{\circ} \mathrm{C}, 20 \mathrm{~min}\right)$ for separation of serum. The obtained serum was used to analyze liver enzymes and proinflammatory cytokines.Thereafter, animals were killed, livers were separately dissected and blood was washed off with cold saline then livers were immediately flash frozen in liquid nitrogen and kept at $-80^{\circ} \mathrm{c}$ for measurement of tissue parameters.

\section{Plant material and extraction}

Leaves of Zizyphus spina christi (L.) wild were collected from plants growing in the vicinity of Zagazig city, Sharkya governorate, Egypt. The plant was kindly verified by Dr. Abdel Baset, Faculty of Sciences, Zagazig University. A voucher specimen was deposited at the Department of Pharmacology, Faculty of Pharmacy, Zagazig University.

About $1800 \mathrm{~g}$ of the dried plant materials were ground to a fine powder and extracted with $70 \% \mathrm{EtOH}$ in a percolator (5Lx 3). The EtOH extract was concentrated in vacuo to yield $185 \mathrm{~g}$ of viscous dark green residue.

\section{Preparation of Zizyphus spina christi extract}

$800 \mathrm{mg}$ ZSC dissolved in $10 \mathrm{ml}$ of $8 \%$ Gum acacia

\section{Determination of biochemical parameters:}

The serum alanine aminotransferase (ALT), aspartate aminotransferase (AST) level were measured using a colorimetric method as described by Murry (1984) and Young (1995), alkaline phosphatase (ALP) level was measured using colorimetric method as described by Young (1975) and lactate dehydrogenase (LDH) level was 
measured using a fixed rate kinetic method as described by Pesce (1984).

\section{Determination of proinflammatory and anti-inflammatory cytokines:}

The TNF- $\alpha$ and IL-10 levelsin liver was measured by ELISA according to (Yan-Lian et al., 1994), using the kit provided by $\mathbf{R} \& \mathbf{D}$ system, USA.TNF$\alpha / \mathrm{IL}-10$ was mathematically calculated.

\section{Determination of oxidative stress:}

The generation of reactive oxygen species in response to hepatic ischemia/reperfusion injury was determined in liver tissues by the measurement of the lipid peroxidation product content,malondialdehyde (MDA), reduced glutathione (GSH) activity, Nitric oxide content (NO) and superoxide dismutase (SOD) activity.MDA was determined ) using the kit provided by Diamond diagnostic, Egypt following the protocol described by (Ohkawa et al., 1979),SOD was measured using the kit provided by Biodiagnostic, Egypt following the protocol described by (Nishikimi et al., 1972), where GSH was measured using the kit provided by Biodiagnostic, Egypt following the protocol described by (Beutler et al., 1963) and NO was measured using a colorimetric method as described by Montgomery and Dymock (1961).

\section{Drugs and chemicals:}

Gum acacia was purchased from El- Gomhouria Company; Cairo, Egypt, Pentobarbital sodium was gifted from Faculty of Faculty of Pharmacy, Zagazig University Egypt, Dimethyl sulfoxide (DMSO) was purchased from Fluca Sigma, Germany. Leaves of Zizyphus spina christi (L.) wild were collected from plants growing in the vicinity of
Zagazig city, Sharkya governorate, Egypt and BAGDE was purchased from Sigma, USA.

\section{Statistical analysis:}

Data were analyzed using computer based fitting program (Prism, Graphpad 5). The results expressed as mean values \pm SE were compared between groups using one-way analysis of variance (ANOVA) followed by Newman-Keul's post hoc test as post test. Differences were considered to be statistically significant when $\mathrm{P}<0.05$.

\section{RESULTS:}

\section{1- Effect on liver enzymes}

Compared with the sham group, 45 minutes ischemia followed by 1 hour reperfusion resulted in a significant $P$ $<0.05$ increase in serum AST, ALT, ALP and $\mathrm{LDH}$ activities $(776 \%, 675 \%, 436 \%$ and $594 \%$, respectively). Pretreatment with ZSC extract ( $400 \mathrm{mg} / \mathrm{kg}$ orally) significant $\mathrm{P}<0.05$ decrease in serum AST, ALT, ALP and LDH (35\%, 29\%, 38\% and $31 \%$ respectively) compared to hepatic I/R rats.On the other hand, pretreatment with BADGE $(30 \mathrm{mg} / \mathrm{kg})$ 30 minutes before administration of ZSC extract resulted in a significant $\mathrm{P}<0.05$ attenuation of the ZSC extract effects with remarkable increase in serum AST, ALT, ALP and $\mathrm{LDH}(235 \%, 278 \%, 198 \%$ and $257 \%$ respectively) compared to ZSC extract alone (Table 1).

\section{2- Effect on inflammatory and anti- inflammatory cytokines}

As shown in table (2) induction of hepatic I/R in rats showed a significant $\mathrm{P}<0.05$ elevation ofinflammatory cytokine TNF- $\alpha$ by $748 \%$ and significant reduction in antiinflammatory mediators IL-10 by $15 \%$ as compared with the sham group. Pretreatment with ZSC extract (400 mg/ kg orally) produced a significant $\mathrm{P}<0.05$ decrease TNF- $\alpha$ by $27 \%$ and significant elevation in serum IL-10 by $426 \%$ compared to hepatic I/R 
rats.Pretreatment with BADGE $(30 \mathrm{mg} / \mathrm{kg}) 30$ minutes before administration of ZSC extract resulted in a significant $\mathrm{P}<0.05$ attenuation of the ZSC extract effects with remarkable increase in TNF- $\alpha$ by $295 \%$ and significant reduction in serum IL-10 by $34 \%$ compared to $Z S C$ extract.

\section{3- Effect on oxidative stress}

Table (3) demonstrated that induction of hepatic $\mathrm{I} / \mathrm{R}$ in rats showed a significant $\mathrm{P}<0.05$ reduction in hepatic GSH $(21 \%)$ content and SOD (15\%) content and significant $\mathrm{P}<0.05$ increase in hepatic NO (426\%) content and MDA $(668 \%)$ content as compared with the sham group. While, Pretreatment with ZSC extract $(400 \mathrm{mg} / \mathrm{kg}$ orally) produced a significant $\mathrm{P}<0.05$ increase in hepatic GSH $(285 \%)$ content and SOD $(378 \%)$ content and significant lowering in hepatic NO (37\%) content and MDA (34\%) content compared to hepatic $I / R$ rats. The pretreatment with BADGE $(30 \mathrm{mg} / \mathrm{kg}) \quad 30$ minutes before administration of $Z S C$ extract resulted in a significant $\mathrm{P}<0.05$ attenuation of the $Z S C$ extract effects showed a decrease in hepatic GSH content by $45 \%$ and SOD content by $36 \%$ compared to ZSC extract and significant increase in hepatic NO content by $197 \%$ and MDA content by $251 \%$ compared to ZSC extract.

Table (1): The effect of hepatic I/R, oral administration of ZSC extract (400 mg/ kg) and I.P administration ofBADGE (30 mg/kg) /ZSC extract $(400 \mathrm{mg} / \mathrm{kg}$ orally) on liver enzymes (serum AST, ALT, ALP and LDH activities in rats):

\begin{tabular}{|lllll|}
\hline Parameters & Sham & I/R & ZSC extract & BADGE/ ZSC \\
\hline AST (U/L) & $23.5 \pm 0.84$ & $182.2 \pm 4.31$ & $63.33 \pm 2.99^{*}$ & $149.3 \pm 2.26^{* @}$ \\
ALT (U/L) & $22.33 \pm 1.35$ & $150.7 \pm 4.32$ & $43.67 \pm 1.78^{*}$ & $121.5 \pm 1.31^{* @}$ \\
ALP (U/L) & $44.50 \pm 2.46$ & $194.3 \pm 5.46$ & $74.67 \pm 2.81^{*}$ & $148.0 \pm 1.18^{* @}$ \\
LDH (U/L) & $28.83 \pm 1.25$ & $171.3 \pm 4.22$ & $53.33 \pm 2.96^{*}$ & $137.5 \pm 1.12^{* @}$ \\
\hline
\end{tabular}

Data are presented as mean \pm S.E.M.

*Significantly different from control ischemic group at $\mathrm{P}<0.05$

@ Significantly different from zisyphus treated group at $\mathrm{P}<0.05$

Table (2): The effect of hepatic I/R, oral administration of ZSC extract (400 mg/ kg) and I.P administration ofBADGE (30 mg/kg) /ZSC extract $(400 \mathrm{mg} / \mathrm{kg}$ orally) on inflammatory cytokines (TNF- $\alpha$ ) and anti-inflammatory cytokines (IL-10) in rats.

\begin{tabular}{|llccl|}
\hline Parameters & Sham & I/R & ZSC extract & BADGE/ ZSC \\
\hline TNF- $\alpha(\mathrm{pg} / \mathrm{ml})$ & $23.22 \pm 1.26$ & $173.6 \pm 5.08$ & $46.93 \pm 3.62^{*}$ & $138.6 \pm 1.011^{* @}$ \\
IL-10 $(\mathrm{pg} / \mathrm{ml})$ & $122.5 \pm 5.23$ & $19.05 \pm 1.31$ & $81.23 \pm 3.56^{*}$ & $27.60 \pm 0.59$ \\
\hline
\end{tabular}

Data are presented as mean \pm S.E.M.

*Significantly different from control ischemic group at $\mathrm{P}<0.05$

@ Significantly different from zisyphus treated group at $\mathrm{P}<0.05$ 
Table (3): The effect of hepatic I/R, oral administration of $Z S C$ extract $(400 \mathrm{mg} / \mathrm{kg})$ and I.P administration ofBADGE $(30 \mathrm{mg} / \mathrm{kg}) / Z S C$ extract $(400 \mathrm{mg} / \mathrm{kg}$ orally) on liver oxidative stress ( SOD, GSH, NO and MDA) in rats.

\begin{tabular}{|lllll|}
\hline Parameters & Sham & I/R & ZSC extract & BADGE/ ZSC \\
\hline GSH $(\mu \mathrm{mol} / \mathrm{g})$ & $2.87 \pm 0.12$ & $0.608 \pm 0.03$ & $1.73 \pm 0.05^{*}$ & $0.777 \pm 0.01^{@}$ \\
SOD $(\mathrm{U} / \mathrm{g})$ & $12.47 \pm 0.534$ & $1.882 \pm 0.092$ & $7.123 \pm 0.282^{*}$ & $2.630 \pm 0.057^{@}$ \\
$\mathrm{NO}(\mu \mathrm{mol} / \mathrm{g})$ & $10.27 \pm 0.459$ & $43.57 \pm 2.506$ & $16.03 \pm 0.718^{*}$ & $31.60 \pm 0.679^{* @}$ \\
$\mathrm{MDA}(\mathrm{nmol} / \mathrm{g})$ & $5.43 \pm 0.330$ & $36.35 \pm 2.467$ & $12.28 \pm 0.630^{*}$ & $30.75 \pm 0.952^{* @}$ \\
\hline
\end{tabular}

Data are presented as mean \pm S.E.M.

*Significantly different from control ischemic group at $\mathrm{P}<0.05$

@ Significantly different from zisyphus treated group at $\mathrm{P}<0.05$

\section{DISCUSSION:}

The present study aimed to investigate the protective, antioxidant, and antiinflammatory effects of ZSC ethanol extract against hepatic $\mathrm{I} / \mathrm{R}$ in rats. In addition, the present work tried to explore the possible mechanisms of action of ZSC. Another interesting target was to investigate the implication of PPAR-y receptor in ZSC actions.

Hepatic ischemia/reperfusion (I/R) injury is one of the main causes of hepatic damage and is inevitable after hepatic surgery, liver transplantation, shock, and trauma (Huguet et al, 1994; Lemasters and Thurman, 1997). Hepatic $\mathrm{I} / \mathrm{R}$ is an intentional procedure which is applied during liver surgery to minimize bleeding of this bloody organ during surgery. Hepatic $I / R$ leads to an acute inflammatory response, causing significant hepatocellular damage and organ dysfunction (Akahori et al., 2007).

In the present model, hepatic I/R was induced by clamping the branches of the hepatic artery and hepatic portal vein supplying the left lateral and median lobes ( about $70 \%$ of the area of the liver) for 45 minutes followed by one hour of reperfusion. This model has been widely used in different studies (Farmer et al., 2002; Arii et al., 2003).

Results of the present study reveal strong and promising antioxidant activity of ZSC extract against hepatic I/R injury. ZSC extract was administered in a dose of 400 $\mathrm{mg} / \mathrm{kg}$ orally 60 minutes prior to induction of ischemia. Although no sufficiently long treatment regimen was applied, ZSC extract showed strong antioxidant property. This was demonstrated by significant $(\mathrm{P}<0.05)$ increase of antioxidant enzymes, SOD activity (378\%) and GSH content $(285 \%)$ in the liver tissues as well as significant $(\mathrm{P}<0.05)$ reduction in $\mathrm{NO}(37 \%)$ and MDA (34\%) contents in the liver tissues compared to the control I/R group. This antioxidant capacity of ZSC extract maintained the integrity of the cell membranes which in turn, significantly $(\mathrm{P}<0.05)$ decreased the leakage of liver ALT, AST, LDH and ALP (35\%, 29\%, 38\% and 31\% respectively), compared to the control I/R group, to blood circulation. This antioxidant activity could be related to the presence of flavonoids content of ZSC extract as reported by Kim et al. (2004). In addition to that, the anti-lipid 
peroxidase effect of ZSC has been proposed as one of the possible mechanisms for its protective actions against ischemia reperfusion injury to the liver.

Our results are in accordance with Chen et al. (2010) who suggested that pretreatment with an extract of ZJ, which shows high antioxidant effects, significantly attenuated the I/R-induced liver injury by significantly attenuated blood levels of alanine transaminase (ALT), lactic dehydrogenase (LDH), oxygen radical $(\mathrm{OH})$, and nitric oxide (NO).

These results also are in agreement with the findings of Amin and Ghoneim (2009) who found that, oral administration of ZSC resulted in a significant amelioration of liver injury judged by the reduced activities of serum ALT and AST. Moreover, ZSC has also restored normal levels of malondialdehyde and retained control activities of endogenous antioxidants such as SOD, CAT and GSH. Studies on the antioxidant properties of flavonoids from various plant extracts reveal their stimulatory action on antioxidative enzymes (Nagata et al., 1999; Sreelatha et al., 2009). Taken together; these findings indicate that ZSC exerts a protective effects against liver I/R injury, possibly through its antioxidant action.

Among natural antioxidants present in the body are, GSH, SOD and catalase. SOD provides a defense strategy against the potentially damaging reactivities of superoxide radical anion $\left(\mathrm{O}_{2}^{-{ }^{-}}\right)$in cells through catalyzing the dimutation of two $\mathrm{O}_{2}$ to $\mathrm{H}_{2} \mathrm{O}_{2}$ (Halliwell and Gutteridge, 1990). Reducedglutathione (GSH) acts directly as a free radical scavenger by neutralizing free radicals such as $\mathrm{HO}^{\prime}$, restores damaged molecules by hydrogen donation, reduces peroxides and maintains protein thiols in the reduced state (Navarro et al., 1999). Catalase is a major hydrogen peroxide detoxifying enzyme also utilizes NADPH, which protects the protein from inactivation by its substrate $\mathrm{H}_{2} \mathrm{O}_{2}$ (Gaetani et al., 1989; Gaetaniet al., 1994).

Nitric oxide (NO) is recognized as a mediator and regulator of inflammatory processes. A significantly increased amount of NO synthesized by inducible nitric oxide synthase (iNOS) participates in provoking inflammatory process and acts synergistically with other inflammatory mediators (Aktan, 2004).

For the expression of iNOS, the mammalian cells should be triggered by specific stimulants, such as proinflammatory cytokines and bacterial lipopolysaccharide (Chesrown et al., 1994). Suppression of iNOS is believed to be closely linked with the anti-inflammatory action. Therefore, inhibition of iNOS activity or down-regulation of iNOS expression represented as lower amounts of NO may be beneficial to reduce the inflammatory response. It can be noticed that, there is an inhibitory action of the ZSC extract on NO release; this may suggests that the anti-inflammatory mechanism of action may be at least in part due to NO inhibition. This suggestion is in harmony with our suggestion that NO release from macrophages model to evaluate the antiinflammatory activity of the ZSC $70 \%$ ethanolic extract leaves.

The effect of ZSC extract on NO release may be due to the flavonoidal contents of the extract including quercetin, since Kim et al., (2004) has been reported that, using LPS /cytokine-treated macrophages or macrophage-like cell lines, some varieties of flavonoids including, apigenin, luteolin and quercetin were found to inhibit NO production.

On the other hand, it was shown in the present investigation that, the pretreatment with ZSC extract 60 minutes prior I/R 
produced a significant $(\mathrm{P}<0.05)$ reduction in TNF- $\alpha \quad(27 \%)$ and significant $(\mathrm{P}<0.05)$ increase in IL-10 (426\%) in serum compared to the control I/R group, giving another evidence on the anti-inflammatory properties of ZSC extract may has, that can be mediated through its inhibitory effect on TNF- $\alpha$ release. Interleukin-10 (IL-10) is a potent anti-inflammatory cytokine that inhibits the synthesis of pro-inflammatory cytokines by T-helper lymphocytes, monocytes and neutrophils (Moore et al., 1993). Moreover, Yoshidome et al. (1999) demonstrated that, intravenous IL-10 injections after hepatic I/R protected against the liver damage by suppressing NFkB activation and subsequent expression of proinflammatory mediators. The results of the present study also supported by other reports of Aeii et al. (2003) and Montalvo-Java et al. (2008).

It seems likely that, the antiinflammatory activity of ZSC extractinvitro is probably due to the presence of the flavonoids, quercetin as reported by Shahat et al. (2001) and rutin as stated by Brantner and Males (1999), since a study done by Lanni and Becker (1985) showed that quercetin was repeatedly found to inhibit phospholipase $\mathrm{A}_{2} \quad\left(\mathrm{PLA}_{2}\right)$ from several sources. It inhibited PLA2 from rabbit peritoneal neutrophils with an IC50 of 57 100 M. Moreover, it was found by Wadsworth and Koop (2001) that quercetin can inhibit iNOS expression and thus possesses anti-inflammatory property. This suggestion is in confirmation with Wadsworth et al. (2001) who stated that; quercetin has inhibitory properties against TNF- $\alpha$ induction from LPS-induced RAW cells.

Furthermore, this study investigated the probable role of PPAR- $\gamma$ in mediating ZSC extract protection against hepatic I/R-induced damage. This was achieved by comparing the protective capacity of ZSC extract in presence and in absence of PPAR-y antagonist, BADGE. BADGE was administered i.p. 30 minutes prior to ZSC extract administration in a dose of $30 \mathrm{mg} / \mathrm{kg}$ in order to completely block PPAR- $\gamma$. It was found that administration of BADGE prior administration of ZSC extract significantly $(\mathrm{P}<0.05)$ attenuated the action of ZSC extract. These outcomes may suggest that ZSC may be acting in part through activating PPAR-y in the liver.

In conclusion, depending on the results obtained from the present study, it seems likely that, ZSC extract the ZSCmediated protection against liver injury may be due to the antioxidant and inflammation. Further studies are currently underway to characterize the detailed mechanism of action of ZSC in an attempt to introduce it as a reliable option for treating liver fibrosis.

\section{REFERENCES}

Abdel-Wahhab, M.; Abdel-Galil, M.M.; Hassan, A.M.; Hassan, N.S.; Nada, S.A.; Saeed, A. (2005). Zizyphu sspina christi protects against aflatoxin B1-initiated hepatic carcinogenicity. Toxo Letters. 158S: S1-S258.

Abdel-Zaher, A.O.; Salem, S.Y.; Assaf, M.H.; Abdel-Hady, R.H. (2005): Antidiabetic activity and toxicity of Zizyphus spina christileaves. J Ethnopharmacol. 101: 129-138.

Adzu, B.; Amos, S.; Wambebe, C.; Gamaniel, K. (2001). Antinociceptive activity of the aqueous extract of Zizyphus spina christi root bark. Fitoterapia. 72: 344350 .

Aeii, S.; Teramoto, K.; and Kawamura, T. (2003): Current progress in the understanding of and therapeutic strategies for ischemia and reperfusion injury in liver. J. Hebatibiliary Pancreat. 
Surg. 10: 189-194.

Akahori, T.; Sho M.; Hamada, K.; Suzaki, Y.; Kuzumoto, Y.; Nomi, T.; Nakamura, S.; Enomoto, K.; Kanehiro, H.; and Nakajima, Y. (2007): Importance of peroxisome proliferator-activated receptor-y in hepatic ischemiareperfusion injury in mice. $\mathrm{J}$. Hepatol.:47: 784-792.

Aktan, F. (2004). INOS-mediated nitric oxide production and its regulation. Life Sci. 75: 639-653.

Amin, A.; and Ghoneim, D. M. (2009): Zizyphus spina christi protects against carbon tetrachloride-induced liver fibrosis in rats. Food and Chemical Toxicology 47: 2111-2119

Beutler, E.; Duron, O.;and Kelly, L. (1963): Improved method for the determination of blood glutathione. J.Lab. Clin. Med. 61: 882-888.

Borgi, W.; Ghedira, K.; Chouchane, N. (2007).Anti-inflammatory and analgesic activities of Zizyphus lotus root barks. Fitoterapia. 78: 16-19.

Brantner, A.H.; Males, Z. (1999).Quality assessment of Paliurusspina christi extracts. J Ethnopharmacol. 66: 175-179.

Chen, C.F.; Lee, J.F.; Wang, D.; Shen, C.Y.; Shen, K.L.; and Lin, M.H. (2010): Water Extract of Zizyphus jujube Attenuates Ischemia/Reperfusion-Induced Liver Injury in Rats (PP106). Transplantation Proceedings, 42, 741-743.

Chesrown, S.E.; Monnier, J.; Visner, G.; Nick, H.S. (1994). Regulation of inducible nitric oxide synthase mRNA levels by LPS, INF-gamma, TGF beta, and IL-10 in murine macrophage cell lines and rat peritoneal macrophages. Biochem Biophys Res Commun. 200:126-134.

Farmer, D.G.; Amersi, F.; Kupiec-Weglinski, J. ; and Burutti, R.W. (2002): Current status of ischemia and reperfusion injury in the liver. Transplant. Rev. 14(2): 106126.

Gaetani, G.F.; Galiano, S.; Canepa, L.; Ferraris, A.M.; Kirkman, H.N. (1989). Catalase and glutathione peroxidase are equally active in detoxification of hydrogen peroxide in human erythrocytes. Blood.73: 334-339.

Gaetani, G.F.; Kirkman, H.N.; Mangerini, R.; Ferraris, A.M. (1994).Importance of catalase in the disposal of hydrogen peroxide within human erythrocytes. Blood.84: 325-330.

Glombitza, K.W.; Mahran, G.H.; Mirhom, Y.W.; Michel, K.G.; Motawi, T.K. (1994): Hypoglycemic and antihyperglycemic effects of Zizyphusspina christi in rats. Planta Med. 60: 244-247.

Halliwell, B.; Gutteridge, J.M., (1990). Role of free radicals and catalytic metal ions in human disease: an overview. Methods Enzymol. 186: 1-85.

Huguet, C.; Gavelli, A.; and Bona, S. (1994): Hepatic resection with ischemia of the liver exceeding one hour. J. Am. Coll. Surg. 178: 454-458.

Kim, H.P.; Son, K.H.; Chang, H.W.; Kang, S.S. (2004). Anti-inflammatory Plant Flavonoids and Cellular Action Mechanisms.J Pharmacol Sci. 96: 229245.

Lemasters, J.J. ; and Thurman, R.G. (1997): Reperfusion injury after liver preservation for transplantation. Annu. Rev. Pharmacol. Toxicol. 37:327-338.

Montalvo-Java, E.E.; Escalante-Tattersfield, T.; Ortega-Salgado, J.A.; Pina, E.; and Geller, D.A. (2008): Factors in the pathophysiology of the liver ischemia/reperfusion injury. J. Surg. Res. 147: 153-159.

Montgomery, H.A.; and Dymock, J.S. (1961): 
Nitric oxide. Analyst; 86: 414.

Moore, K.W.; O'Garra A.; de Waal Malefyt, R.; Vieira, P.; and Mosmann, T.R. (1993): Interleukin-10. Annu. Rev. Immunol.; 11: 165-90.

Murry, R. (1984). Alanine aminotransferase. In "Kaplan A. et al"., Clin.Chem. Pp.10881090.Mosby, St. Louis.

Nagata, H.; Takekoshi, S.; Takagi, T.; Honma, T.; Watanabe, K. (1999). Antioxidative action of flavonoids, quercetin and catechin, mediated by the activation of glutathione peroxidase.Tokai J. Expt. Clin. Med. 24: 1-11.

Navarro, J.; Obrador, E.; Carretero, J.; Petschen, I.; Avino , J.; Perez, P.; Estrela, J.M. (1999). Changes in glutathione status and the antioxidant system in blood and in cancer cells associate with tumor growth in vivo. Free Radic Biol Med. 26: 410-418.

Nishikimi, M.; Appaji Rao, N. ;and Yagi, K. (1972): The occurrence of superoxide anion in the reaction of reduced phenazine methosulfate and molecular oxygen. Biochemical and Biophysical Research Communications 46: 849-854.

Nunes, P.H.; Marinho, L.C.; Nunes, M.L.; Soares, E.O. (1987). Antipyretic activity of an aqueous extract of Zizyphus joazeiro Mart (Rhamnaceae).Braz J Med Biol Res. 20: 599-601.

Ohkawa, H.; Ohishi, N. ; and Yagi, K. (1979): Assay for lipid peroxides in animal tissues by thiobarbituric acid reaction. Analytical Biochemistry. 95: 351-358.

Pesce, A. (1984). Lactate dehydrogenase. In "Kaplan A. et al"., Clin.Chem. pp.117, 438.Mosby, St. Louis.

Shahat, A.A.; Pieters, L.; Apers, S.; Nazeif, N.M.; Abdel-Azim, N.S.; VandenBerghe, D.; Vlietinck, A.J., (2001). Chemical and biological investigations on Zizyphusspina christi L. Phytother Res. 15: 593-597.

Shaojun, L.; Zhiheng, C. ; Dongbo, C.; Fen, L.; Xiaoyan, W.; Lian, Z.; Rui, L.; and Zhiming, X. (2013): A Study on the Protective Effect of Silybum marianum Extract on Hepatic IschemiaReperfusion Injury. Afr J Tradit Complement Altern Med., 10(5): 310312.

Sreelatha, S.; Padma, P.R.; Umadevi, M. (2009). Protective effects of Coriandrum sativum extracts on carbon tetrachlorideinduced hepatotoxicity in rats. Food Chem. Toxicol. 47, 702-708.

Wadsworth, T.L.; Koop, D.R. (2001).Effects of Ginkgo biloba extract (EGb 761) and quercetin on lipopolysaccharide-induced release of nitric oxide.Chem Biol Interact. 137: 43-58.

Yan-Lian, C.; Le Vraux, V.; Giroud, J.P. ;and Chauvelot-Moachon, L. (1994): Antitumor necrosis factor properties of nonpeptide drugs in acute-phase responses. European Journal of Pharmacology. 271: 319-327.

Yoshidome, H.; Kato, A.; Edwards, M.J.; and Lentsh, A.B. (1999): Interleukin-10 suppresses hepatic ischemia/reperfusion injury in mice: implication of a central role for nuclear factor kappaB. Hepatology; 30: 203-08

Young, D.S. (1975). Alkaline phosphatase. Clin. Chem. 21:5.

Young, D.S. (1995). Effects of drugs on clinical lab. Tests. $4^{\text {th }}$ ed. AC. Press.

Zhang, W.; Wang, M.; Xie, H.Y.; Zhou, L.; Meng, X.Q.; Shi, J.; and Zheng, S. (2007): Role of reactive oxygen species in mediating Hepatic ischemiareperfusion injury and its therapeutic applications in liver transplantation. Transp. Proc. 39: 1332-1337. 
دراسة للتأثثير الوقائى لخلاصة نبات السدر (زيزيفس سبينا كريستى) ضد التلف الكبدى المحدث بالقصور الاموي

\section{شيماء حسن الفيومي, محمد نجيب زكريا حسن, نبيلة نور الدين المراغي}

قسم الفارماكولوجي, كلية الصيدلة, جامعة الزقازيق

استهدفت هذة الدراسة تقييم الدور الوقائى لمضادات الأكسدة والألتهاب لمستخلص نبات السدركأحدالنواتج الطبيعية ضد نقص الدموية ومايتبعة من اعادة السريان المسبب لاصابة الكبد بحالة مرضية.كذلك نظرة دقيقة فى احتمالية قيام مستخلص نبات السدر بدوره الوقائى من خلال مستقبلات مكثر البروكسيزوم النشط - جاما بمقارنة هذا الدور فى وجود أو عدم وجود مادة بيفسفينول أ دايجليسيديل ايثر. وقد قسمت الجرذان الى أربعة مجموعات. مجموعة (1): تم حقنهابمادة كلوريد الصوديوم (0.9\% مجم/كجم) عن طريق الحقن فى التجويف البريتونى ثم احداث حبس الدموية ثم اعادة السريان وهى تمثل المجموعة الضابطة لحبس الدموية ثم اعادة السريان فى الكبد. مجموعة (2): تم حقنها بالمستخلص الكوحولى 70\% لنبات السدر (400 مج/كجم) عن طريق الفم قبل العملية الجر احية و احداث حبس الدموية بساعة .والمجموعة (3): نم حقنها بمادة بيفسفيول أ دايجليسيديل ايثر (30 مجم/كجم) عن طريق الحقن فى التجويف البريتونى قبل التجريع بالمستخلص الكحولى 70\% لنبات السدر بثلاثين دقيقة. ترتب على احداث حبس الدموية ثم اعادة السريان فى الكبد زيادة جوهرية فى نشاط انزيمات الكبد: أسبارتات أمينوتر انسفيريز, ألانين أمينوتر انسفيريز, فوفسفاتيز القاعدى و لاكتات ديهايدروجينيز وكذلك مستوى معامل نخر الأورام-ألفا, ونقص جوهرى فى انترلوكين-10 فى مصل الدم كما أحدث زيادة جوهرية فى محتوى أكسيد النتريك ومحتوى مالون داى الديهايد فى أنسجة الكبد ونقص جو هرى فى نشاط انزيم سوبر أكسيد ديسميوتيز ومحتوى جلوناثيون المختزل فى الكبد أوضحت الدر اسة أن لمستخلص نبات السدر دور وقائى ضد الضرر الناتج عن حبس الدموية ثم اعادة السريان فى الكبد من خلال كونه مضادا للأكسدة ليس فقط لكونه محبط للشو ارد الحرة بل لتأثثره المحافظ على انزيمات الكبد وكونه مضاد للألتهابات. من جهة أخرى أوضحت الدراسة ان اعطاء مادة بيفسفينول أ دايجليسيديل ايثر (30 مجم/كجم) عن طريق الحقن فى بل التجويف البريتونى قبل التجريع بمستخلص نبات السدر(400 مجم/كجم) بثلاثين دقيقة يقلل من التأثير الوقائى لنبات السدر بشكل جوهري فى المؤشرات. ومن ناحية أخرى وجد فى هذه الدراسة أن التأثثر الوقائى لنبات السدر يمكن أن يكون عن طريق تحفيذ مستقبلات البروكسيزوم النشطــ ألفا 